\title{
GMR
}

\section{Genetic divergence through joint analysis of morphoagronomic and molecular characters in accessions of Jatropha curcas}

\author{
C.N. Pestana-Caldas, S.A. Silva, E.L. Machado, D.R. de Souza, \\ E.C. Cerqueira-Pereira and M.S. Silva \\ Núcleo de Melhoramento Genético e Biotecnologia, \\ Centro de Ciências Agrárias, Ambientais e Biológicas, \\ Universidade Federal do Recôncavo da Bahia, Cruz das Almas, BA, Brasil \\ Corresponding author: E.L. Machado \\ E-mail: ednalobomachado5@gmail.com
}

Genet. Mol. Res. 15 (4): gmr. 15048385

Received January 5, 2016

Accepted August 8, 2016

Published October 5, 2016

DOI http://dx.doi.org/10.4238/gmr.15048385

Copyright $(92016$ The Authors. This is an open-access article distributed under the terms of the Creative Commons Attribution ShareAlike (CC BY-SA) 4.0 License.

\begin{abstract}
The aim of this study was to investigate the genetic divergence between accessions of Jatropha curcas through joint analysis of morphoagronomic and molecular characters. To this end, we investigated 11 morphoagronomic characters and performed molecular genotyping, using 23 inter-simple sequence repeat (ISSR) primers in 46 accessions of $J$. curcas. We calculated the contribution of each character on divergence using analysis of variance. The grouping among accessions was performed using the Ward-MLM (modified location model) method, using morphoagronomic and molecular data, whereas the cophenetic correlation was obtained based on Gower's algorithm. There were significant differences in all growth-related characteristics: number of primary and secondary branches per plant, plant height, and
\end{abstract}


stem diameter. For characters related to grain production, differences were found for number of fruit clusters per plant and number of inflorescence clusters per plant and average number of seeds per fruit. The greatest phenotypic variation was found in plant height (59.67$222.33 \mathrm{~cm}$ ), whereas the smallest variation was found in average number of seeds per fruit (0-2.90), followed by the number of fruit clusters per plant (0-8.67). In total, 94 polymorphic ISSR fragments were obtained. The genotypic grouping identified six groups, indicating that there is genetic divergence among the accessions. The most promising crossings for future hybridization were identified among accessions UFRB60 and UFVJC45, and UFRB61 and UFVJC18. In conclusion, the joint analysis of morphoagronomic characters and ISSR markers is an efficient method to assess the genetic divergence in J. curcas.

Key words: Genetic improvement; ISSR Marker; Jatropha curcas L.

\section{INTRODUCTION}

Jatropha curcas $\mathrm{L}$. is an oleaginous plant with a seed oil content ranging between 30 and $40 \%$ (Freitas et al., 2011). It therefore has great potential for use in the National Program for the Production and Use of Biodiesel (Saturnino et al., 2005; Laviola et al., 2013). The Jatropha culturing does not compete directly with food or agriculture and is compatible with the profile of family agriculture (Rosado et al., 2010; Laviola et al., 2013). In addition, compared to the oil of other species such as soybean, castor, and palm, top quality is observed in terms of oxidation stability, viscosity, and freezing point (Carels, 2009). However, it is still in the process of domestication and there are currently no consolidated cultivars (Durães et al., 2011; Laviola et al., 2014). The improvement work is in the early stages of development, mainly because some agronomic attributes have not yet been achieved, including non-uniformity on fruit maturation, production, and harvest (Durães et al., 2011; Brasileiro et al., 2012; Oliveira et al., 2013).

Knowledge about the genetic variability of $J$. curcas is necessary for the selection of divergent and contrasting accessions that can be used to obtain superior genetic constitutions, formation of clones, and/or species hybrids. Thus, the morphoagronomic characterization of Jatropha is an important tool for obtaining genetic information about the phenotype, in order to identify accessions with different genetic constitutions. Molecular markers are fundamental in the study of genetic divergence, by enabling evaluation of a large number of accessions in the short term. This is possible because of their high degree of polymorphism and because they are not influenced by the environment. In addition, variability in the genome independent of the developmental stage of the plant can be detected using molecular markers (Ferreira and Grattapaglia, 2008). Inter-simple sequence repeat (ISSR) molecular markers are widely used in studies of genetic diversity (Rosado et al., 2010; Grativol et al., 2011; Santana et al., 2011). They have also been applied to population genetics, plant identification, and the study of gene flow and paternity analyses (Reddy et al., 2002).

Amore complete analysis of the germplasm of Jatropha can be done using a combination of morphological characters and molecular markers (Faleiro, 2007). When evaluated in

Genetics and Molecular Research 15 (4): gmr.15048385 
isolation, experimental variables do not provide the complete information necessary for disregarding existing correlations between the variables. However, when investigated at the same time, we may find linear dependence or correlations among the variables and, with this information, we can sort and group the obtained values and investigate the dependence among the variables. The present study aimed to study the genetic divergence between accessions of $J$. curcas, using morphoagronomic characters and ISSR molecular markers. This information will assist programs of genetic improvement of this species.

\section{MATERIAL AND METHODS}

This study was conducted in the municipality of Cruz das Almas, Bahia, located at $12^{\circ} 40^{\prime} 12^{\prime \prime} \mathrm{W}$ and $39^{\circ} 06^{\prime} 07^{\prime \prime} \mathrm{S}$, at an average elevation of $226 \mathrm{~m}$. The climate in the area is hot and humid. The average annual rainfall is $1224 \mathrm{~mm}$ (ranging between 900 and $1300 \mathrm{~mm}$ ), with the months of March to August being the wettest, and September to February the driest. The annual average temperature is $24.1^{\circ} \mathrm{C}$ and the relative humidity is $80 \%$.

An active germplasm bank was formed using random blocks design with 46 accessions and 22 repetitions, in linear installments with 46 plants, each spaced $3 \times 2 \mathrm{~m}$ apart. The identification and origin of the accessions of Jatropha are presented in Table 1.

\section{Morphoagronomic characterization}

The evaluation included 11 morphoagronomic characters, using three assessments in distinct seasons in 2013. The assessments were performed in February, June, and December, when the plants were 32, 36 and 46 months of age, respectively. The characters evaluated were: plant height (PH: the distance between the surface of the soil and the apical end of the last leaf); stem diameter (SD: measured at the bottom of the stem, as close to the ground as possible, using calipers); number of primary (NPB) and secondary (NSB) branches per plant (obtained by direct counting of the number of branches inserted into the main stem); number of fruits per plant (NF); number of fruit clusters per plant (NBFP), number of inflorescence clusters per plant (NIBP); number of seeds per plant (NS); average number of seeds per fruit (NSF: direct count); fruit weight per plant (FW); and seed weight per plant (SW), using a digital Mars semi-analytic scale model AL 500C.

\section{Genotyping}

DNA extraction was performed according to the protocol described by Doyle and Doyle (1990). The DNA quantity and quality were evaluated by comparative analysis with known concentrations of lambda DNA (Invitrogen, Carlsbad, CA, USA) on $0.8 \%$ agarose gel, stained with ethidium bromide $(0.5 \mathrm{mg} / \mathrm{mL})$. The samples were diluted in Tris-EDTA, to adjust the concentration to $5 \mathrm{ng} / \mu \mathrm{L}$.

Initially, we performed a trial with the amplification of the DNA of only two accessions (UFRB22 and UFVJC45), for selection of primers with good amplification patterns. A total of 103 oligonucleotide ISSRs were used in this initial screening. Each amplification reaction was prepared in a final volume of $20 \mu \mathrm{L}$ containing $20 \mathrm{ng}$ DNA, $1 \mathrm{X}$ buffer $(50 \mathrm{mM}$ Tris- $\mathrm{HCl}$, $20 \mathrm{mM} \mathrm{KCl}$ ), $0.2 \mathrm{mM}$ dNTPs mix, $1.5 \mathrm{mM} \mathrm{MgCl}, 0.3 \mu \mathrm{M}$ each primer (synthesized by Invitrogen), and $0.2 \mathrm{U} / \mu \mathrm{L} \mathrm{Taq}$ DNA polymerase (Invitrogen).

Genetics and Molecular Research 15 (4): gmr.15048385 
Table 1. Jatropha accession with their identification names, origin, altitude, and geographical information about the collection sites, experimental stations, and plantations in the State of Bahia, Cruz das Almas, BA, Brazil, 2015.

\begin{tabular}{|c|c|c|c|}
\hline Genotype & Origin & Altitude (m) & Latitude/longitude \\
\hline UFRB22 & Jequié & 233 & $13^{\circ} 52.388^{\prime} \mathrm{W} / 40^{\circ} 03.810^{\prime} \mathrm{S}$ \\
\hline UFRB23 & Jequié & 252 & $13^{\circ} 51.878^{\prime} \mathrm{W} / 40^{\circ} 03.678^{\prime} \mathrm{S}$ \\
\hline UFRB24 & Jequié & 236 & $13^{\circ} 51.794^{\prime} \mathrm{W} / 40^{\circ} 03.857^{\prime} \mathrm{S}$ \\
\hline UFRB27 & Terezinha & 179 & $13^{\circ} 59.708^{\prime} \mathrm{W} / 39^{\circ} 46.343^{\prime} \mathrm{S}$ \\
\hline UFRB28 & Ipiaú - Itaibo & 206 & $13^{\circ} 56.437^{\prime} \mathrm{W} / 39^{\circ} 44.224^{\prime} \mathrm{S}$ \\
\hline UFRB29 & Ipiaú - Itaibo & 202 & $13^{\circ} 56.502^{\prime} \mathrm{W} / 39^{\circ} 44.255^{\prime} \mathrm{S}$ \\
\hline UFRB30 & Ipiaú - Itaibo & 218 & $13^{\circ} 56.460^{\prime} \mathrm{W} / 39^{\circ} 44.192^{\prime} \mathrm{S}$ \\
\hline UFRB31 & Apaurema & 295 & $13^{\circ} 51.594^{\prime} \mathrm{W} / 39^{\circ} 44.700^{\prime} \mathrm{S}$ \\
\hline UFRB32 & Apaurema & 307 & $13^{\circ} 51.744^{\prime} \mathrm{W} / 39^{\circ} 44.829^{\prime} \mathrm{S}$ \\
\hline UFRB33 & Apaurema & 271 & $13^{\circ} 50.999^{\prime} \mathrm{W} / 39^{\circ} 42.129^{\prime} \mathrm{S}$ \\
\hline UFRB35 & Itaitê - Santa Clara & 317 & $12^{\circ} 56.188^{\prime} \mathrm{W} / 41^{\circ} 03.765^{\prime} \mathrm{S}$ \\
\hline UFRB36 & Itaitê - Santa Clara & 317 & $12^{\circ} 56.192^{\prime} \mathrm{W} / 41^{\circ} 03.761^{\prime} \mathrm{S}$ \\
\hline UFRB37 & Itaitê - Santa Clara & 317 & $12^{\circ} 56.194^{\prime} \mathrm{W} / 41^{\circ} 03.759^{\prime} \mathrm{S}$ \\
\hline UFRB38 & Itaitê - Santa Clara & 317 & $12^{\circ} 56.181^{\prime} \mathrm{W} / 41^{\circ} 03.777^{\prime} \mathrm{S}$ \\
\hline UFRB39 & Iraquara & 907 & $12^{\circ} 34.729^{\prime} \mathrm{W} / 41^{\circ} 34.923^{\prime} \mathrm{S}$ \\
\hline UFRB40 & Itaitê - Santa Clara & 318 & $12^{\circ} 56.183^{\prime} \mathrm{W} / 41^{\circ} 03.790^{\prime} \mathrm{S}$ \\
\hline UFRB41 & Andaraí - Igatu & 742 & $12^{\circ} 53.826^{\prime} \mathrm{W} / 41^{\circ} 19.072^{\prime} \mathrm{S}$ \\
\hline UFRB42 & Andaraí - Igatu & 766 & $12^{\circ} 53.834^{\prime} \mathrm{W} / 41^{\circ} 19.222^{\prime} \mathrm{S}$ \\
\hline UFRB43 & Andaraí - Igatu & 749 & $12^{\circ} 53.600^{\prime} \mathrm{W} / 41^{\circ} 19.250^{\prime} \mathrm{S}$ \\
\hline UFRB44 & Mucugê - Guiné & 983 & $12^{\circ} 46.364^{\prime} \mathrm{W} / 41^{\circ} 32.216^{\prime} \mathrm{S}$ \\
\hline UFRB45 & Mucugê - Guiné & 966 & $12^{\circ} 45.270^{\prime} \mathrm{W} / 41^{\circ} 32.568^{\prime} \mathrm{S}$ \\
\hline UFRB47 & Palmeiras & 673 & $12^{\circ} 30.946^{\prime} \mathrm{W} / 41^{\circ} 34.627^{\prime} \mathrm{S}$ \\
\hline UFRB50 & Faz. Pau-Ferro & 692 & $12^{\circ} 31.747^{\prime} \mathrm{W} / 41^{\circ} 34.100^{\prime} \mathrm{S}$ \\
\hline UFRB53 & Faz. Pau-Ferro & 691 & $12^{\circ} 31.749^{\prime} \mathrm{W} / 41^{\circ} 34.096^{\prime} \mathrm{S}$ \\
\hline UFRB54 & Iraquara & 713 & $12^{\circ} 20.570^{\prime} \mathrm{W} / 41^{\circ} 35.644^{\prime} \mathrm{S}$ \\
\hline UFRB55 & Souto Soares & 712 & $12^{\circ} 20.566^{\prime} \mathrm{W} / 41^{\circ} 35.630^{\prime} \mathrm{S}$ \\
\hline UFRB56 & Cafarnaum** & 841 & $12^{\circ} 01.086^{\prime} \mathrm{W} / 41^{\circ} 40.138^{\prime} \mathrm{S}$ \\
\hline UFRB58 & Wagner & 789 & $11^{\circ} 46.246^{\prime} \mathrm{W} / 41^{\circ} 09.284^{\prime} \mathrm{S}$ \\
\hline UFRB59 & Gambá & 256 & $12^{\circ} 17.121^{\prime} \mathrm{W} / 41^{\circ} 08.346^{\prime} \mathrm{S}$ \\
\hline UFRB60 & Gambá & 527 & $12^{\circ} 17.119^{\prime} \mathrm{W} / 41^{\circ} 08.340^{\prime} \mathrm{S}$ \\
\hline UFRB61 & C. do Sincorá & - & - \\
\hline UFRB62 & Santa Inês & 384 & $13^{\circ} 17.158^{\prime} \mathrm{W} / 39^{\circ} 49.397^{\prime} \mathrm{S}$ \\
\hline UFVJC03 & Santa Citória-MG* & - & - \\
\hline UFVJC05 & João pinheiro-MG* & - & - \\
\hline UFVJC10 & João pinheiro-MG* & - & - \\
\hline UFVJC18 & Montalvânia-MG* & - & - \\
\hline UFVJC19 & Montalvânia-MG* & - & - \\
\hline UFVJC23 & Caratinga-MG* & - & - \\
\hline UFVJC40 & Formoso-TO* & - & - \\
\hline UFVJC41 & Jales-SP* & - & - \\
\hline UFVJC45 & B. dos Bugres-MT* & - & - \\
\hline UFVJC46 & B. dos Bugres-MT* & - & - \\
\hline UFVJC52 & Barbacena-MG* & - & - \\
\hline UFVJC65 & Unknown* & - & - \\
\hline UFVJC74 & Cambodia* & - & - \\
\hline UFVJC84 & Petrolina-PE* & - & - \\
\hline
\end{tabular}

**Commercial planting, *genotype introduced by means of exchange, non-sampled plants.

The amplification conditions were performed according to the protocol proposed by Williams et al. (1990). The samples were amplified in a Veriti 96-well thermal cycler (Applied Biosystems), using a program with an initial cycle at $94^{\circ} \mathrm{C}$ for $1 \mathrm{~min}$, followed by 40 cycles of $94^{\circ} \mathrm{C}$ for $30 \mathrm{~s}, 35^{\circ} \mathrm{C}$ for $30 \mathrm{~s}$, and $72^{\circ} \mathrm{C}$ for $1 \mathrm{~min}$. This was followed by a final extension of $7 \mathrm{~min}$ at $72^{\circ} \mathrm{C}$.

The electrophoresis was conducted on $1.5 \%$ agarose gel $(\mathrm{p} / \mathrm{v})$ stained with $0.5 \mathrm{mg} /$ $\mathrm{mL}$ ethidium bromide in 1X TBE buffer ( $89 \mathrm{mM}$ Tris-Borate, $2 \mathrm{mM}$ EDTA) for about 1:40 h. We used a 1-kb DNA ladder as molecular weight standard (Promega, Maidson, WI, EUA).

Genetics and Molecular Research 15 (4): gmr.15048385 
The fragments were visualized under UV light and photo-documented using the digital system digital loccus biotechnology (Molecular Imagine).

\section{Data analysis}

The morphagronomic data were analyzed by analysis of variance (ANOVA). For each of the morphoagronomic characters, we calculated the contribution to divergence between accessions through the Genes software (Cruz, 2013). For the joint analyses, we used the means obtained from the eleven morphoagronomic characters and the codification of the ISSRs markers. Since the ISSR marker is a dominant marker, the data were computed as absence (0) and presence (1) of visible gel bands. The grouping was constructed using the Ward-MLM (modified location model) method through the R statistical software (R Development Core Team, 2006). The cophenetic correlation between the distance matrix and the grouping matrix, as estimated through the joint analysis, was obtained based on Gower's algorithm (Gower, 1971), expressed by:

$$
S_{i j k}=\frac{\sum_{k=1}^{p} W_{i j k} \cdot S_{i j k}}{\sum_{K=1}^{p} W_{i j k}}
$$

in which $\mathrm{k}=$ the number of variables $(\mathrm{k}=1,2, \ldots, \mathrm{p})$; $\mathrm{i}$ and $\mathrm{j}$ are two individuals representing the access; $\mathrm{w}_{\mathrm{ijk}}=$ weight given to the comparison ijk, assigning a value of 1 for valid comparisons and 0 to invalid comparisons (when the value of the variable is missing for one or both individuals); and $\mathrm{S}_{\mathrm{ijk}}=$ contribution of the variable $\mathrm{k}$ in the dissimilarity between the individuals $\mathrm{i}$ and $\mathrm{j}$, with values between 0 and 1 through the $\mathrm{R}$ statistical software ( $\mathrm{R}$ Development Core Team, 2006).

A dendrogram was generated using Statistica v. 6.0 (Statsoft, 2002) and the number of groups was set using the NbClust R package (Charrad et al., 2014) using the pseudo- $\mathrm{t}^{2}$ criterion.

\section{RESULTS AND DISCUSSION}

The descriptive statistics and ANOVA results of the morphoagronomic descriptors are presented in Table 2 . There were significant differences $(\mathrm{P} \leq 0.05)$ in all growth-related characters, including NPB, NSB, $\mathrm{PH}$, and SD. The characters related to grain production showed significant differences $(\mathrm{P} \leq 0.01)$ for the characters NBFP, NIBP, and NSF. The coefficient of variation ranged from $15.23 \%$ for $\mathrm{SD}$ to $182.52 \%$ for $\mathrm{FW}$. The greatest phenotypic variation was found in PH $(59.67-222.33 \mathrm{~cm})$, with an average of $157.86 \mathrm{~cm}$, whereas the smallest variation was found in NSF ( 0 to 2.90 ) with an average of 0.63 , followed by NBFP showing values between 0 and 8.67, with an average of 1.06. Similar results were observed by Laviola et al. (2011) in 175 accessions of Jatropha. The authors observed differences for all traits evaluated, for example NPB, SD, and production of grain (Laviola et al., 2011).

Among the 11 morphoagronomic characters evaluated, SW contributed the most $(19.84 \%)$ to the genetic divergence among the 46 accesses (Table 3), followed by FW $(12.79 \%)$ and $\mathrm{PH}(12.59 \%)$. The character that least contributed to the variability was NS

Genetics and Molecular Research 15 (4): gmr.15048385 
Table 2. Summary of ANOVAs of 46 accession of Jatropha curcas evaluated at 32, 36, and 42 months after planting. Cruz das Almas, BA, Brazil, 2015.

\begin{tabular}{|c|c|c|c|c|c|c|c|c|}
\hline & d.f. & & & Average squ & growth-r & characters & & \\
\hline & & & & NRSB & & $\mathrm{PH}$ & & \\
\hline Blocks & 21 & & & 338.42 & & 2308.38 & & \\
\hline TRAT & 45 & & & $175.30^{* * *}$ & & $1715.17 * *$ & & \\
\hline Residue & 945 & & & 70.33 & & 589.49 & & \\
\hline Average & & & & 15.33 & & 157.86 & & \\
\hline CV (\%) & & & & 54.71 & & 15.38 & & \\
\hline Minimum & & & & 0.00 & & 59.67 & & \\
\hline Maximum & & & & 66.67 & & 222.33 & & \\
\hline & & & & iverage squ & rain proc & characters & & \\
\hline & & NBFP & NIBP & $\mathrm{NF}$ & FW & SW & NSF & NS \\
\hline Blocks & 21 & 2.81 & 14.80 & 6.19 & 30.49 & 16.90 & 1.03 & 44.58 \\
\hline TRAT & 45 & $3.46^{* *}$ & $15.03^{* *}$ & $5.359^{\text {ns }}$ & $22.77^{\mathrm{ns}}$ & $12.42^{\text {ns }}$ & $0.70 * *$ & $38.10^{\mathrm{ns}}$ \\
\hline Residue & 945 & 1.44 & 9.45 & 4.21 & 18.68 & 9.90 & 0.37 & 29.96 \\
\hline Average & & 1.06 & 2.66 & 1.21 & 2.37 & 1.74 & 0.63 & 3.22 \\
\hline CV (\%) & & 113.54 & 115.66 & 169.05 & 182.52 & 181.22 & 96.93 & 169.77 \\
\hline Minimum & & 0.00 & 0.00 & 0.00 & 0.00 & 0.00 & 0.00 & 0.00 \\
\hline Maximum & & 8.67 & 40.00 & 25.67 & 68.38 & 49.17 & 2.90 & 68.67 \\
\hline
\end{tabular}

**Significant at $\mathrm{P} \leq 0.01 ; \mathrm{ns}=$ not significant $(\mathrm{P} \geq 0.05)$. Number of primary (NPB) and secondary (NSB) branches; plant height (PH, cm); stem diameter (SD); number of fruit plant clusters (NBFP); number of inflorescence clusters per plant (NIBP); number of fruits per plant (NF); fruit weight per plant (FW, g); seed weight per plant (SW, g); average number of seeds per fruit (NSF); number of seeds per plant (NS).

Table 3. Relative contribution (\%) of each of the characters obtained from the Jatropha curcas active germplasm bank to divergence. Cruz das Almas, BA, Brazil, 2015.

\begin{tabular}{l|c}
\hline Character & Contribution (\%) \\
\hline Number of primary branches & 5.75 \\
\hline Number of secondary branches & 8.87 \\
\hline Plant height (cm) & 12.59 \\
\hline Stem diameter & 10.41 \\
\hline Number of fruit clusters & 9.71 \\
\hline Number of inflorescences & 4.25 \\
\hline Number of fruits & 8.04 \\
\hline Fruit weight (g) & 12.79 \\
\hline Seed weight (g) & 19.84 \\
\hline Average number of seeds per fruit & 5.79 \\
\hline Number of seeds per plant & 1.97 \\
\hline
\end{tabular}

(1.97\%). Laviola et al. (2011) noted that the quantitative characters that contributed most to the genetic divergence in 175 accesses of $J$. curcas in descending order were age, grain production, stem diameter, height, number of secondary branches, crown projection in line with the height, the height of the first inflorescence, and projection of the cup between lines. Moreover, Santana et al. (2013) studied nine hybrid combinations of $J$. curcas and observed that the character that most contributed to the genetic divergence $(21 \%)$ was the number of female flowers, followed by stem diameter (17\%), seed production $(15 \%)$, and number of secondary branches $(14 \%)$. In contrast, the characters that least contributed to the genetic divergence were plant height (13\%), mass of 100 seeds $(10 \%)$, branch height $(8 \%)$, combinatorial ability and the genetic parameters of $J$. curcas accessions (2\%) (Santana et al., 2013). 
Of the 103 ISSR primers tested here, 23 resulted in good patterns and were therefore selected for genotyping of all 46 Jatropha accessions (Table 4). All 23 ISSR primers used produced polymorphic fragments. The size ranges of the fragments varied between 90 and $1550 \mathrm{bp}$, with the largest variation found in primer 914 TriCGA3'RC (90-1500 bp). This primer generated a total of six fragments with $100 \%$ polymorphism (Table 4). A greater variation in fragment size was obtained by Basha et al. (2009) and Sunil et al. (2008) when studying genetic diversity in Jatropha. Using ISSRs markers, they recorded fragments ranging between 100-3500 and 250-3000 bp, respectively. From the 112 fragments obtained here, $94(84 \%)$ were polymorphic and $18(16 \%)$ monomorphic, revealing genetic variability among the studied accessions. Each primer produced an average of 4.6 fragments, of which 3.9 showed polymorphism. The smallest variation in the number of polymorphic fragments was found in primers 839 (DIGA3'C) and 885 (TriACC3'RC), with one polymorphic fragment, whereas the largest variation was found in 843 (DIGA5' $\mathrm{C}$ ), with eight polymorphic fragments.

Table 4. ISSR primers used for genotyping of 46 accession of Jatropha curcas.

\begin{tabular}{|c|c|c|c|c|c|}
\hline Number & Primer & Sequence $5^{\prime} \rightarrow 3^{\prime}$ & Polymorphic & Monomorphic & Total \\
\hline 839 & DIGA3'C $^{\prime}$ & GAGAGAGAGAGAGAGAC & 1 & 1 & 2 \\
\hline 840 & DIGA3'RC & GAGAGAGAGAGAGAGARC & 5 & 1 & 6 \\
\hline 841 & DIGA3'T & GAGAGAGAGAGAGAGAT & 3 & 1 & 4 \\
\hline 842 & DIGA3'YC & GAGAGAGAGAGAGAGAYC & 3 & 1 & 4 \\
\hline 843 & DIGA5'C & CGAGAGAGAGAGAGAGA & 8 & 0 & 8 \\
\hline 845 & DIGA5'CY & CYGAGAGAGAGAGAGAGA & 6 & 3 & 9 \\
\hline 846 & DIGA5'T & TGAGAGAGAGAGAGAGA & 4 & 0 & 4 \\
\hline 851 & DIGT3'YG & GTGTGTGTGTGTGTGTYG & 2 & 0 & 2 \\
\hline 852 & DIGT5'A & AGTGTGTGTGTGTGTGT & 3 & 1 & 4 \\
\hline 853 & $\mathrm{DIGT5}^{\prime} \mathrm{C}$ & CGTGTGTGTGTGTGTGT & 2 & 1 & 3 \\
\hline 855 & DIGT5'CY & CYGTGTGTGTGTGTGTGT & 2 & 0 & 2 \\
\hline 857 & TriCAC3'RC & CACCACCACCACCACRC & 3 & 0 & 3 \\
\hline 859 & TriCAC5'CR & CRCACCACCACCACCAC & 5 & 2 & 7 \\
\hline 861 & TriCAG & CAGCAGCAGCAGCAG & 3 & 1 & 4 \\
\hline 864 & TriCAG5'CR & CRCAGCAGCAGCAGCAG & 3 & 1 & 4 \\
\hline 869 & TriGTG5'CR & CRGTGGTGGTGGTGGTG & 6 & 1 & 7 \\
\hline 885 & TriACC3'RC & ACCACCACCACCACCRC & 1 & 1 & 2 \\
\hline 887 & TriAGA3'RC & AGAAGAAGAAGAAGARC & 4 & 0 & 4 \\
\hline 903 & TriTGC3'RC & TGCTGCTGCTGCTGCRC & 5 & 0 & 5 \\
\hline 912 & TriCCT3'RC & CCTCCTCCTCCTCCTRC & 3 & 1 & 4 \\
\hline 914 & TriCGA3'RC & CGACGACGACGACGARC & 6 & 0 & 6 \\
\hline 917 & TriCGG3'RC & CGGCGGCGGCGGCGGRC & 3 & 0 & 3 \\
\hline 930 & TriGGT3'RC & GGTGGTGGTGGTGGTRC & 5 & 1 & 6 \\
\hline Total & & & 94 & 18 & 112 \\
\hline
\end{tabular}

The high degree of polymorphism obtained (84\%), suggests that the ISSR markers were efficient in the detection of genetic variability. He et al. (2007), Kumar et al. (2008), and Ram et al. (2008) obtained similar results. However, in other studies using ISSR molecular markers, Basha and Sujatha (2007) and Oliveira et al. (2013) reported low genetic divergence in the $J$. curcas germplasm.

The genetic distance was obtained on the number of discrepancies between the accessions, observed in a genetic dissimilarity of 46 accessions, from data of morphoagronomic and molecula characterization (Table 5). The genetic distance analysis revealed variation ranging from 0.52 to 0.06 between hits and an average distance of 0.28 . The most genetically similar accessions UFRB60 and UFVJC45, were found to have the minimum genetically 
C.N. Pestana-Caldas et al.

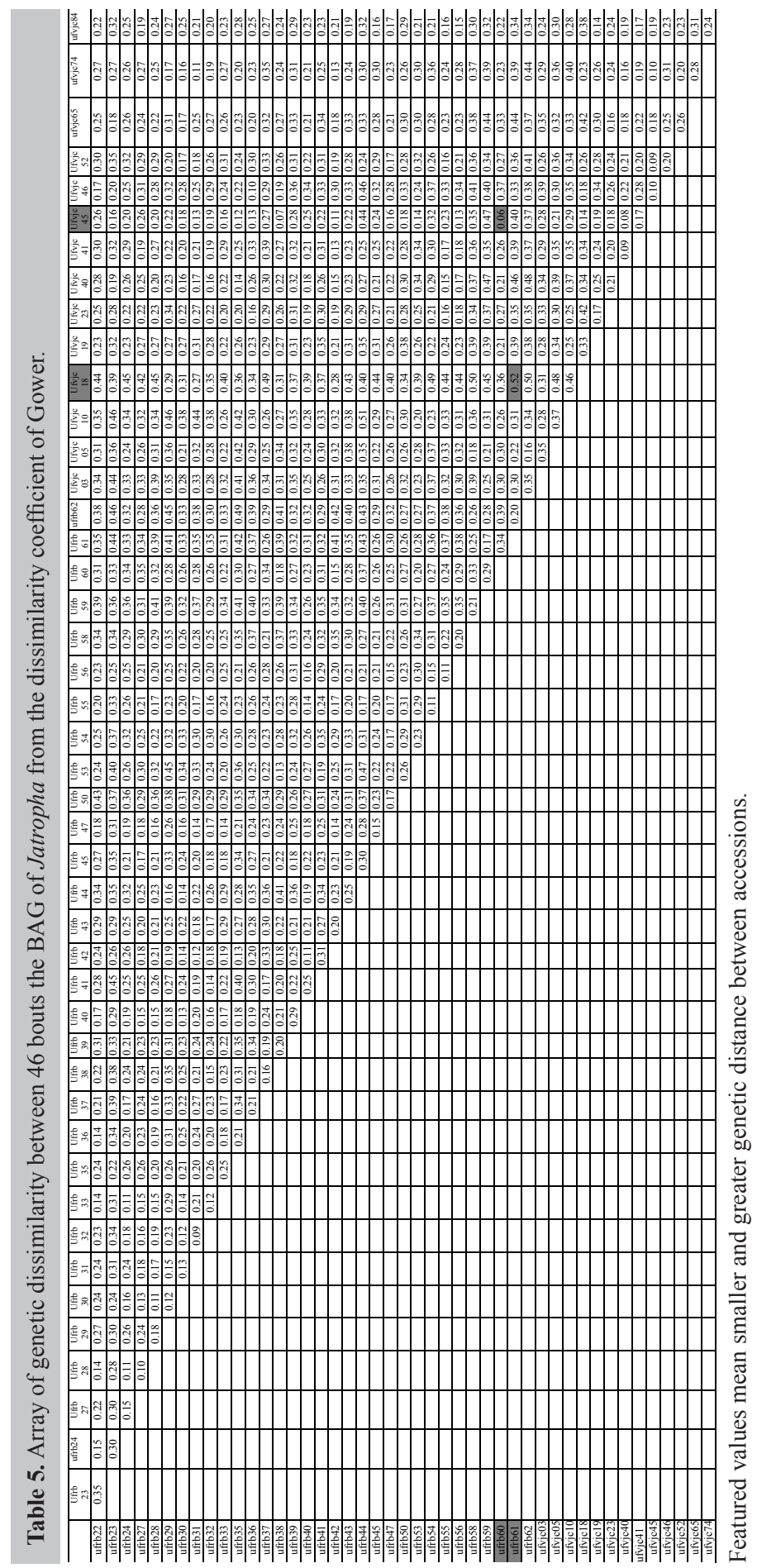

Genetics and Molecular Research 15 (4): gmr.15048385 
similarity value of 0.06 , whereas the most genetically dissimilar accessions were UFRB61 and UFVJC18, with the maximum value of 0.52 . This cross may be used in the selection of promising genetic constitutions for future associations within the program of genetic improvement of Jatropha. Other promising combinations would be UFVJC10 and UFRB44; UFVJC18 and UFRB58; and UFVJC18 and UFRB62 with the genetic dissimilarity values of $0.51,0.50$, and 0.50 , respectively.

Similar results were found by Alves et al. (2013), studying the genetic variability in 117 Jatropha accessions using a joint analysis of phenotypic and molecular data (RAPD and SSR). They calculated the genetic dissimilarity matrix values based on Gower's method (Gower, 1971) and found genetic distance variation ranging from 0.06 to 0.48 between accessions, with an average distance of 0.20 (Alves et al., 2013). Rosado et al. (2009) studied the genetic diversity of 192 Jatropha accessions and found variation ranging from 0.14 to 1.0 between accessions, using RAPD and SSR markers.

The dendrogram obtained using the Ward-MLM method, divided the 46 accessions of $J$. curcas into six distinct groups. The grouping of hits is shown in Figure 1. Groups 1 and 3 each contained $26 \%$ of all accessions, whereas groups $2,4,5$, and 6 contained 17, 7, 13, and $11 \%$, respectively, of all 46 accessions evaluated. This suggests that there was genetic dissimilarity between them.

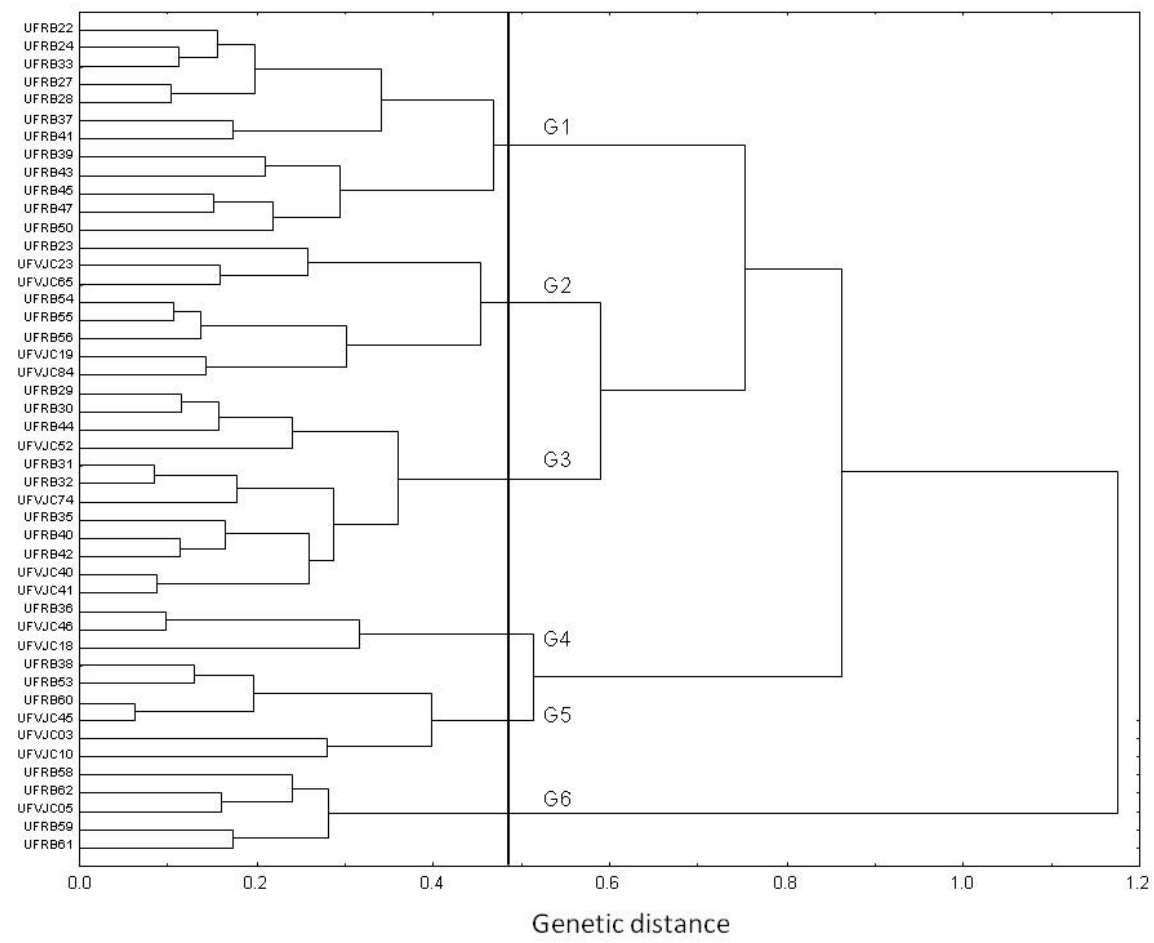

Figure 1. Matrix of genetic dissimilarity between 46 accessions of Jatropha curcas obtained using the Ward-MLM method based on Gower's dissimilarity coefficient. X-axis: access of Jatropha curcas; Y-axis: genetic distance; centerline: court score; G1-G6: number of groups.

Genetics and Molecular Research 15 (4): gmr.15048385 
These results corroborate those found by Oliveira et al. (2013). Using 30 RAPD primers, they evaluated the genetic variability among 40 accessions of $J$. curcas and found six distinct groups, which confirms the presence of genetic variability among them (Oliveira et al., 2013). Similarly, a study of genetic variability in 72 accessions of Jatropha from 13 different countries, using RAPD and ISSR markers, identified eight different groups (Basha et al., 2009). Alves et al. (2013) found contrasting results, when studying genetic variability in 117 Jatropha accessions through the joint analysis of phenotypic and molecular data (RAPD and SSR). A dendrogram based on the Tocher method divided the accessions into 14 distinct groups, although most of the accessions were designated to a single group (Alves et al., 2013).

Studies using joint analysis of morphoagronomic and molecular data in Jatropha are still quite limited, although a few examples, such as the study by Alves et al. (2013), can be found in the literature. Using the joint analysis of morphoagronomic and molecular characters, the identification of genetic constitutions that are promising for future associations is made possible. This provides discriminatory power in forming groups that generate information that may be used for genetic improvement of Jatropha and provides better knowledge about the genetics of the species.

To conclude, we found evidence of genetic variability among accessions of J. curcas in the UFRB/NBIO active germplasm bank consisting of six distinct groups. This joint analysis of morphoagronomic and molecular data demonstrates the potential of the accessions for the genetic improvement program of the species. The most genetically dissimilar accessions were UFRB61 with UFVJC18, suggesting that these accessions may be especially promising is future breeding programs.

\section{Conflicts of interest}

The authors declare no conflict of interest.

\section{ACKNOWLEDGMENTS}

Research supported by Conselho Nacional de Desenvolvimento Científico e Tecnológico $(\mathrm{CNPq})$ and Coordenação de Aperfeiçoamento de Pessoal de Nível Superior (CAPES).

\section{REFERENCES}

Alves AA, Bhering LL, Rosado TB, Laviola BG, et al. (2013). Joint analysis of phenotypic and molecular diversity provides new insights on the genetic variability of the Brazilian physic nut germplasm bank. Genet. Mol. Biol. 36: 371-381. http://dx.doi.org/10.1590/S1415-47572013005000033

Basha SD and Sujatha M (2007). Inter and intra-population variability of Jatropha curcas (L.) characterized by RAPD and ISSR markers and development of population-specific SCAR markers. Euphytica 156: 375-386. http://dx.doi. org $/ 10.1007 / \mathrm{s} 10681-007-9387-5$

Basha SD, Francis G, Makkar HPS, Becker K, et al. (2009). A comparative study of biochemical traits and molecular markers for assessment of genetic relationships between Jatropha curcas L. germplasm from different countries. Plant Sci. 176: 812-823. http://dx.doi.org/10.1016/j.plantsci.2009.03.008

Brasileiro BP, Silva SA, Souza DR, Oliveira RS, et al. (2012). Conservação de pinhão-manso (Jatropha curcas L.) no estado da Bahia, Brasil. Magistra 24: 286-292.

Carels N (2009). Chapter 2 Jatropha curcas: A Rreview. Adv. Bot. Res. 50: 39-86. http://dx.doi.org/10.1016/S00652296(08)00802-1

Genetics and Molecular Research 15 (4): gmr.15048385 
Charrad M, Ghazzali N, Boitenau V and Niknafs A (2014). NbClust: An R Package for Determining the Relevant Number of Clusters in a Data Set. J. Stat. Softw. 61: 1-36. http://dx.doi.org/10.18637/jss.v061.i06

Cruz CD (2013). GENES - a software package for analysis in experimental statistics and quantitative genetics. Acta Sci. Agron. 35: 271-276. http://dx.doi.org/10.4025/actasciagron.v35i3.21251

Doyle JJ and Doyle JL (1990). A rapid total DNA preparation procedure for fresh plant tissue. Focus 12: 13-15.

Durães FOM, Laviola BG and Alves AA (2011). Potential and challenges in making physic nut (Jatropha curcas L.) a viable biofuel crop: the Brazilian perspective. CAB Rev. Perspect. Agric. Vet. Sci. Nutr. Nat. Resour. 6: 1-8.

Faleiro FG (2007). Marcadores genéticos-moleculares aplicados a programas de conservação e uso de recursos genéticos. Embrapa Cerrados, Planaltina, 102.

Ferreira ME and Grattapaglia D (2008). Introdução ao uso de marcadores moleculares em análise genética. 3rd edn. Embrapa Cenargen, Brasília, 220.

Freitas RG, Missio RF, Matos FS, Resende MDV, et al. (2011). Genetic evaluation of Jatropha curcas: an important oilseed for biodiesel production. Genet. Mol. Res. 10: 1490-1498. http://dx.doi.org/10.4238/vol10-3gmr1146

Gower JC (1971). A general coefficient of similarity and some of its properties. Biometrics 27: 857-874. http://dx.doi. org $/ 10.2307 / 2528823$

Grativol C, da Fonseca Lira-Medeiros C, Hemerly AS and Ferreira PC (2011). High efficiency and reliability of intersimple sequence repeats (ISSR) markers for evaluation of genetic diversity in Brazilian cultivated Jatropha curcas L. accessions. Mol. Biol. Rep. 38: 4245-4256. http://dx.doi.org/10.1007/s11033-010-0547-7

He W, Guo L, Wang LYW, et al. (2007). ISSR analysis of genetic diversity of Jatropha curcas L. Chin. J. Appl. Environ. Biol. 13: 466-470.

Kumar RS, Parthiban KT and Rao MG (2009). Molecular characterization of Jatropha genetic resources through intersimple sequence repeat (ISSR) markers. Mol. Biol. Rep. 36: 1951-1956. http://dx.doi.org/10.1007/s11033-008-9404-3

Laviola BG, Bhering LL, Mendonça S, Rosado LTB, et al. (2011). Caracterização morfo-agronômica do banco de germoplasma de pinhao manso na fase jovem. Biosci. J. 3: 371-379.

Laviola BG, Alves AA, Rocha RB and Drumond MA (2013). The importance of Jatropha for Brazil. In: Jatropha, challenges for a new energy crop. Volume 1: Farming, economics and biofuel (Carels N, Sujatha B and Bahadur B, eds.). Springer, New York, 71-94.

Laviola BG, Silva SDA, Juhász AC P, Rocha RB, et al. (2014). Desempenho agronômico e ganho genético pela seleção de pinhão-manso em três regiões do Brasil. Pesq. Agropec. Bras. 49: 356-363.</edb>

Oliveira VD, Rabbani ARC, Silva AVC and Lédo AS (2013). Genetic variability in physic nuts cultivated in Northeastern Brazil. Cienc. Rural 43: 978-984. http://dx.doi.org/10.1590/S0103-84782013005000060

R Development Core Team (2006). R: A language and environment for statistical computing. R Foundation for Statistical Computing, Vienna.

Ram SG, Parthiban KT, Kumar RS, Thiruvengadam V, et al. (2008). Genetic diversity among Jatropha species as revealed by RAPD markers. Genet. Resour. Crop Evol. 55: 803-809. http://dx.doi.org/10.1007/s10722-007-9285-7

Reddy M, Sarla N and Siddiq EA (2002). Inter simple sequence repeat (ISSR) polymorphism and its application in plant breeding. Euphytica 128: 9-17. http://dx.doi.org/10.1023/A:1020691618797

Rosado TB, Laviola BG, Pappas MCR, Bhering LL, et al. (2009). Avaliação da diversidade genética do banco de germoplasma de pinhão manso por marcadores moleculares. Embrapa Agroenergia, Brasília, 16.

Rosado TB, Laviola BG, Faria DA, Pappas MR, et al. (2010). Molecular markers reveal limited genetic diversity in a large germplasm collection of the biofuel crop Jatropha curcas L. in Brazil. Crop Sci. 50: 2372-2382. http://dx.doi. org/10.2135/cropsci2010.02.0112

Santana IBB, Oliveira EJ, Soares Filho WS, Ritzinger R, et al. (2011). Variabilidade genética entre acessos de UmbuCajazeira mediante análise de marcadores ISSR. Rev. Bras. Frutic. 33: 868-876. http://dx.doi.org/10.1590/S0100$\underline{29452011005000090}$

Santana UA, Carvalho JLS, Blank AF and Silva-Mann R (2013). Capacidade combinatória e parâmetros genéticos de genótipos de pinhão-manso quanto a caracteres morfoagronômicos. Pesqui. Agropecu. Bras. 48: 1449-1456. http:// dx.doi.org/10.1590/S0100-204X2013001100005

Saturnino HM, Pacheco DD, Kakida J, Tominaga N, et al. (2005). Cultura do pinhão-manso (Jatropha curcas L.). Informe Agropec. 26: 44-78.

Statsoft (2002). Statistica for Windows v. 6.0: Computer Program Manual. StatSoft Inc. Tulsa.

Sunil N, Varaprasad KS, Sivaraj N, Suresh Kumar T, et al. (2008). Assessing Jatropha curcas L. germoplasm in-situ - A case study. Biomass Bioenergy 32: 198-202. http://dx.doi.org/10.1016/j.biombioe.2007.09.003

Williams JG, Kubelik AR, Livak KJ, Rafalski JA, et al. (1990). DNA polymorphisms amplified by arbitrary primers are useful as genetic markers. Nucleic Acids Res. 18: 6531-6535. http://dx.doi.org/10.1093/nar/18.22.6531

Genetics and Molecular Research 15 (4): gmr.15048385 